\title{
Malik Asit Uygulamalarının S.aureus Biyofilmleri Üzerinde Antibiyofilm Etkileri*
}

\author{
Tuğba KÖKÜMER, Meltem YEŞiLÇiMEN AKBAŞ \\ Gebze Teknik Üniversitesi, Moleküler Biyoloji ve Genetik Bölümü, Gebze/Kocaeli
}

Geliș (Received): 18.01.2015

Kabul (Accepted): 23.02.2016

\begin{abstract}
ÖZET: Bu çalışmada, malik asit uygulamalarının $S$. aures biyofilmleri üzerindeki antibiyofilm aktiviteleri incelenmiştir. Biyofilmlerin malik asit uygulamaları ile azalma oranları, klor uygulaması ile karşılaştırılmıştır. Malik asit ve klor uygulamalarının biyofilmler üzerindeki etkileri hem polistren hemde çelik yüzeylerde incelenmiştir. Malik asit uygulamaları, S. aureus biyofilmlerini klor uygulamasından daha etkin bir şekilde engellenmiş ve ortadan kaldırmıştır. Çelik yüzeylerde biyofilmlerin azalma oranlarının daha fazla olduğu belirlenmiştir. Sonuçlar, malik asitin gıda ile temas eden yüzeylerde biyofilm oluşumları için ümit verici çevreyle dost bir uygulama olabileceğini göstermektedir.
\end{abstract}

Anahtar Kelimeler: Biofilm, malik asit, S. aureus, gıda ile temas eden yüzeyler

\section{Antibiofilm Effects of Malic Acid Treatments on S. Aureus Biofilms}

\begin{abstract}
In this study, antibiofilm activities of malic acid treatments on S. aureus biofilmswere investigated. The reduction ratios of biofilms by malic acid treatments were compared with chlorine treatment. The effects of sanitizers on biofilms were evaluated on both on polystyrene and stainless steel surfaces. Malic acid treatment more efficiently inhibitedand removed $S$. aureus biofilms than chlorine treatment.The higher reduction ratios were obtained on stainless steel surfaces. The results show that malic acidcould be a potential promising ecofriendlytreatment for biofilm formations in food contact surfaces.
\end{abstract}

Key Words: Biofilm, malic acid, S. aureus, food contact surfaces

\section{GíRiş}

Staphylococcusaureus suşları insan ve hayvanlar için çok sayıda enfeksiyonlara neden olan firsatçı patojen mikroorganizmalardır. S.aureus suşları, insanların ve sıcakkanlı vücutlarının çeşitli bölgelerinde doğal olarak bulunurlar.S. aureussuşlarına özellikle gidalarda ve gida üretimindeki personel ile hastane personelinde de yaygın biçimde rastlanmaktadır (Rashid ve ark., 2012). Bu patojen mikroorganizma, insanlarda başta deri ve yumuşak doku olmak üzere çeşitli ciddi enfeksiyonlara yol açmaktadır (Mertz ve ark., 2007; van Belkum ve ark., 2009).

S.aureus, çĭ̆ süt ve ürünlerinde sıklıkla rastlanmaktadır. Özellikle mastitis hastalığı görülen hayvanlardan elde edilen sütlerin, patojenik $S$. aureus ile kontamine olma olasılıkları çok yüksektir (Scherrer ve ark., 2004; Peles ve ark., 2007; Günaydın ve ark., 2011). Süt ürünleri arasında sıklıkla peynirlerden kaynaklanan Staphylococcus zehirlenmeleri görülmektedir. Bunun nedeninin, $S$. aureus'un peynir yapım sürecinde gelişerek ürettiği enterotoksinler olduğu bilinmektedir (Durlu-Özkaya ve Cömert, 2008; Zinke ve ark., 2012).

Biyofilm, mikroorganizmaların yüzeye yapışarak ürettikleri ekzopolisakkarit matriks içine gömülü halde, bir yüzeye geri dönüşümsüz olarak tutunmuş olarak oluşturdukları yaşam şeklidir (Flemming ve Wingender, 2010). Biyofilm tabakası, bakterileri antimikrobiyal maddelere karşı koruyan ve özellikle gıda sanayinde sorun yaratan önemli bir oluşumdur (Srey ve ark., 2013). Bunun en önemli sebebi, biyofilm içerisinde bulunan bakterilerin antimikrobiyallere serbest yaşayan formlarına göre çok daha fazla dirençli olmalarındandır (Cos ve ark., 2010; Simoes, 2011).

Özellikle gıda işleme endüstrisindeki farklı yüzeyler bakterilerin tutunması ve biyofilm oluşturmaları için oldukça elverişli ortamlardır. Birçok mikroorganizma gida işleme sanayinde paslanmaz çelik, cam ve teflon gibi yüzeylere tutunarak biyofilm oluşturabilmektedir. $\mathrm{Bu}$ patojen bakterilerin biyofilmleri, üretilen gidaların kontaminasyonuna neden olabilmektedir (Syne ve ark., 2013; Corcoran ve ark., 2014; Di Ciccio ve ark., 2015).

Stafilokokların, çeşitli yüzeylere yapışabilme ve biyofilm oluşturabilme özelliklerinin olduğu bilinmektedir. Stafilokokların biyofilm oluşturmalarında icaADBC gen lokusu tarafindan kodlanan polisakkarit intersellüler adhesin (PIA) en önemli rolü üstlendiği gösterilmiştir (Donlan ve Costerton, 2002; Arciola ve ark., 2015).

Süt endüstrisinde sanitasyon işlemleri her üretim periyodundan sonra yapılmaktadır. Bu nedenle üretilen sütün güvenliğini ve kalitesini arttırmak ancak doğal, ucuz, kalıntı bırakmayan sanitasyon uygulamaları ile mümkün olmaktadır. Günümüzde sıklıkla kullanılan başta klorlu bileşikler ve oksitleyici dezenfektanlar ürün kalitesi bozulmalarına, ekipmanlara, ve çevre ve insan sağlığına olumsuz etkilere yol açmaktadır (Knowless ve ark., 2015). Ayrıca dezenfektan kalıntılarının yoğurt ve peynir starter kültürleri için de inhibe edici etkileri olduğu bilinmektedir (Karagözlü ve Karagözlü, 2004).

Günümüzde tüketicilerin sağlıklı ve doğal ürünlere olan ilgisinin artması nedeni ile yeni ve doğal 
antimikrobiyallere ihtiyaç giderek artmaktadır (Xu ve ark., 2014). Bunlar arasında organik asitler doğal alternatifler arasında yer almaktadır. Organik asitler arasında malik asit birçok gıdada bulunan bir organik asittir. Malik asit uygulamasının Listeria monocytogenes, Escherichia O157:H7 gibi birçok patojen üzerinde antimikrobiyal etkili olduğu bulunmuştur (Raybaudi-Massilia, 2009). Yapılan çalışmalarda malik, sitrik, laktik ve tartarik asitlerin antibakteriyel etkileri olduğu belirlenmiştir (Eswaranandam ve ark., 2004; Lu ve ark., 2011). González -Fandos ve Herera (2013) \%1 ve \%2 konsantrasyonda 5 dakika süre ile malik asit uygulamasını tavuk etleri üzerinde Listeria monocytogenes üzerinde denemişler ve $\% 2$ malik asit uygulamasının inhibitör etkili olduğunu tespit etmişlerdir. Son yıllarda yapılan bir çalışmada $\% 2$ malik asitin 2ppm ozon ile birlikte kullanımının gida temaslı plastik ve PVC (polivinil karbon) yüzeylerde Salmonella Typhimurium'un oluşturduğu biyofilmlerin kontrolü için etkili olduğu rapor edilmiştir (Singla ve ark., 2014). Özellikle mikrotitrasyon plağındaki biyofilm oluşumunda bu uygulama ile 6 kat azalma görülmüștür. $\mathrm{Bu}$ bilgiler doğrultusunda, bugüne kadar malik asit uygulamasının, gıda temaslı yüzeylerde, süt endüstrisinde önemli bir patojen olan $S$. aureus biyofilmlerinin kontrolü için uygulanmasına dayanan herhangi bir çalışma bulunmamaktadır.

Bu çalışmada, çiğ süt örneklerinden izole edilen $S$. aureus suşlarının oluşturduğu biyofilm oluşumunun, doğal bir antibiyofilm ajanı olarak malik asit (10\%) ile engellenmesi ve oluşan biyofilmlerin ortadan kaldırılmasının endüstride sıkılıkla kullanılan klor uygulaması $(200$ ppm) ile karşılaştırılarak incelenmesi amaçlanmıştır.

\section{MATERYAL ve METOT \\ Kullanılan Suşlar ve Bakteri Kültürlerinin Hazırlanması}

Calıșmada, çiğ sütlerden izole edilen 20 adet, vankomisine dirençli, biyofilm pozitif $S$. aureus suşu kullanılmıştır (Akbas ve Kokumer, 2015).

Biyofilm oluşumu, önlenmesi ve ortadan kaldırılması için kullanılacak olan bakteri kültürleri, $S$. aureus suşlarının katı Nutrient agar üzerinde üreyen biriki kolonisinin \%2 (w/v) glukoz içeren TSB (Triptik Soy Broth) besiyerine (TSBG) inokülasyonu ve $37^{\circ} \mathrm{C}$ sıcaklıkta bir gecelik inkübasyonu ile elde edilmiştir. Daha sonra bu kültürler ayrı ayrı TSBG besiyeri ile McFarland değeri 0.5 'e eşit (yaklaşık $10^{8} \mathrm{kob} / \mathrm{ml}$ ) olacak şekilde sulandırılarak biyofilm oluşumunda kullanılmak üzere hazırlanmıștır.

\section{Biyofilm Oluşumunun Polistren Yüzeylerde Önlenmesi}

Steril 96 kuyulu polistren mikrotitrasyon plağ kuyularına $200 \mu 1 \% 10(\mathrm{w} / \mathrm{v})$ konsantrasyonlarda malik asit veya süt işletmelerinde dezenfektan olarak sıklıkla kullanılan $200 \quad$ ppm $\quad(\mathrm{v} / \mathrm{v})$ konsantrasyonda klor solüsyonu ilave edilerek 20 dakika süre ile bekletilmiştir. Uygulama sonrasında kuyular içerisindeki solüsyonlar pipet yardımı ile uzaklaştırılmış, mikrotitrasyon plakları oda sıcaklığında ters çevrilerek 30 dakika süre ile kurutulmuştur.

Biyofilm oluşumu için hazırlanan $S$. aureus suşlarının kültürlerinden, malik asit veya klor uygulanan mikrotitrasyon plağının her bir kuyusuna 1:200 oranında TSBG besiyeri ile birlikte eklenerek $37^{\circ} \mathrm{C}$ sıcaklıkta 48saat süre ile inkübe edilmiştir. İnkübasyondan sonra, kuyulardaki sıvı besiyeri bir pipet ile uzaklaştırılmıştır. Daha sonra kuyular distile su ile 3 kez yıkanarak oda sıcaklığında 30 dakika süre ile kurutulmuştur. Kuyulardaki biyofilm tabakası, \%0.5 (v/v) konsantrasyonda $200 \mu$ l kristal viyole solüsyonu ilave edilerek 15 dakika oda sıcaklığında inkübe edilerek boyanmıştır. Boya pipet ile uzaklaştırıldıktan sonra, boyanın çözünmesi için kuyulara, 200 $\mu 1, \% 33$ glasiyal asitik asit ilave edilerek 10 dakika süre ile bekletilmiştir. Her kuyudan $150 \mu l$ alınarak yeni bir mikrotitrasyon plağına aktarılmıştır. Her kuyunun absorbans değeri 570nm'de bir mikrotitrasyon plağ okuyucusu (BMG Labtech Fluostar Omega ELISA, Almanya) yardımı ile belirlenmiştir. Her suş, her bir uygulama için iki farklı kuyuda, en az 3 tekrarlı şekilde denenmiştir. Sonuçlar, sadece besiyerini içeren (negatif kontrol) ve bakteri suşu inoküle edilen (pozitif kontrol, herhangi bir uygulanma yapılmayan) kuyulardaki absorbans değerleriyle karşılaştırılarak değerlendirilmiştir (Stephanovic ve ark., 2000).

\section{Biyofilm Oluşumunun Polistren Yüzeylerde Ortadan Kaldırılması}

Biyofilm oluşumu için hazırlanan $S$. aureus suşlarının kültürlerinin her biri 1:200 oranında TSBG besiyeri ile birlikte polistren mikrotitrasyon plağ kuyularına eklenerek $37^{\circ} \mathrm{C}$ sıcaklıkta 48 saat süre ile inkübe edilmiştir. İnkübasyondan sonra, kuyulardaki sıvı besiyeri uzaklaştırılmış ve kuyular distile suyla yıkanarak oda sıcaklığında kurutulmuştur. Oluşan biyofilmler malik asit (10\%) veya klor (200 ppm) solüsyonları ile 20 dakika süre ile oda sıcaklığında bekletilmiş, daha sonra pipetle uzaklaştırılarak, yıkanmış ve oda sıcaklığında kurutulmuştur. Biyofilm oluşumunun ortadan kaldırılması kuyuların $\% 0.5(\mathrm{v} / \mathrm{v})$ kristal viyole ile boyaması, boyanın glasiyal asetik asit ile çözündürülmesi ve $570 \mathrm{~nm}$ 'deölçülen absorbans değerleri ile belirlenmiştir. Sonuçlar, sadece besi yerini içeren (negatif kontrol) vebakteri kültürü inoküle edilen (pozitif kontrol, herhangi bir uygulama yapılmayan) kuyulardaki absorbans değerleriyle karşılaştııılarak değerlendirilmiştir.

Biyofilm Oluşumunun Çelik Yüzeylerde Önlenmesi Biyofilm oluşumu için, otoklavda steril edilen paslanmaz çelik kuponlar (20x40x1 mm) 50ml malik asit (\%10) veya klor (200 ppm) solüsyonlarını içeren $100 \mathrm{ml}$ hacimli steril kavanozlar içerisine daldırılmıştır. Çelik kuponlar, daha sonra oda sıcaklı̆̆ında 30 dakika 
süre ile kurutularak $50 \mathrm{ml}$ TSBG besi yeri içeren $10 \mathrm{~m}$ hacimli steril kavanozlar içerisine yerleştirilmiştir. Kavanozlar içerisindeki besi yerleri, hazırlanan bakteri kültürleri ile1:200 oranında ayrı ayrı inoküle edilerek $37^{\circ} \mathrm{C}$ sicaklıkta 48saat süre ile inkübe edilmiştir. İnkübasyondan sonra çelik kuponlar \%0.5 (v/v) kristal viyole içeren steril kavanozlar içerisinde 15 dakika süre ileboyanmıştır. Biyofilm oluşumuna bağlanan boya $50 \mathrm{ml} 33 \%$ glasiyal asitik asit içerisinde çözündürülmüştür. Her kavanozdan $200 \mu$ l çözünen boya alınarak bir mikrotitrasyon plağına aktarılmıştır. Biyofilm oluşumu ve önlenmesi oranları kuyuların absorbans değeri 570nm'de ölçülerek belirlenmiştir. Sonuçlar, sadece besi yerini içeren (negatif kontrol) ve bakteri kültürü inoküle edilen (pozitif kontrol, herhangi bir uygulama yapılmayan) kuyulardaki absorbans değerleriyle karşılaştırılarak değerlendirilmiştir.

\section{Biyofilm Olușumunun Çelik Yüzeylerde Ortadan Kaldırılması}

Oluşan biyofilmlerin ortadan kaldırılması için otoklavda steril edilen paslanmaz çelik kuponlar, $50 \mathrm{ml}$ TSBG besi yeri içeren $100 \mathrm{ml}$ hacimli steril kavanozlar içerisine yerleştirilmiştir. Kavanozlar hazırlanan bakteri kültürleri ile 1:200 oranında ayrı ayrı inoküle edilerek $37^{\circ} \mathrm{C}$ sicaklıkta 48 saat süre ile inkübe edilmiştir. İnkübasyondan sonra, kuponlar yıkanarak kurutulmuştur. Çelik kuponlar 50ml malik asit (\%10) veya klor $(200 \mathrm{ppm})$ solüsyonlarını içeren $100 \mathrm{ml}$ hacimli steril kavanozlar içerisine daldırılarak 20 dakika süre ile oda sıcaklığında bekletilmiştir. Çelik kuponlar yıkanarak kurutulduktan sonra $50 \mathrm{ml} \% 0.5(\mathrm{v} / \mathrm{v})$ kristal viyole içeren $100 \mathrm{ml}$ hacimli steril kavanozlarda boyanmıştır. Biyofilm oluşumuna bağlanan boya $50 \mathrm{ml}$ $33 \%$ glasiyal asitik asit içerinde çözündürülmüş ve her kavanozdan $200 \mu$ l alınarak bir mikrotitrasyon plağına aktarılmıştır. Biyofilım oluşumunun ortadan kaldırılması oranları kuyulardaki çözünen boyanın absorbans değeri 570 nm'de ölçülmesiyle belirlenmiştir. Sonuçlar, sadece besiyerini içeren (negatif kontrol) ve bakteri kültürü inoküle (pozitif kontrol, herhangi bir uygulama yapılmayan) kuyulardaki absorbans değerleriyle karşılaştırılarak değerlendirilmiştir.

Biyofilm oluşumlarının engellenmesi ve ortadan kaldırılmasındaki azalma oranları, malik asit veya klor uygulanmayan biyofilm oluşumlarına göre belirlenmiştir. Biyofilm oluşumu, absorbans değeri (OD $570)>0.1$ durumlarda pozitif ve $<0.1$ durumlarında negatif olarak değerlendirilmiştir.

\section{Istatistiksel Analizler}

İstatistiksel analizler için,varyans analizi (anova) SPSS 11.5 (SPSS Inc.,Chicago, Illinois, USA) programı ile yapılmış ve post hoc Tukey's testi uygulanmıştır. $P<$ 0.05 seviyesinde bulunan denemelerin sonuçları istatistiksel açıdan “önemli” olarak değerlendirilmiştir.
20 adet çiğ süt izolatı $S$. aureus suşunun klor (200 ppm) uygulaması ile mikrotitrasyon plağında biyofilm oluşumunun engellenmesi ve oluşan biyofilmin ortadan kaldırılması oranları (\%) incelenmiştir.

Polistren yüzeylerdeki biyofilm oluşumunda ölçülen absorbans değerleri, çelik yüzeylerdekinden yüksek bulunmuştur.

Biyofilm oluşumlarının 200 ppm klor uygulaması ile bir suşta $\% 51(\mathrm{P}<0.05)$ oranında azaldığ 1 , on suşta ise yaklaşık \%20-\%30 $\quad(\mathrm{P}<0.05) \quad$ oranında önlendiği belirlenmiştir (Çizelge 1).

Çizelge 1. S. aureus suşlarının biyofilm oluşumlarının klor (200 ppm) uygulaması ile polistren yüzeylerde önlenmesi (A) ve ortadan kaldırılması (B) oranları (\%)*

\begin{tabular}{ccc}
\hline Suş & A & B \\
\hline 1 & $15(0.03)$ & $0(0.00)$ \\
2 & $24(0.01)$ & $22(0.00)$ \\
3 & $2(0.03)$ & $40(0.05)$ \\
4 & $20(0.05)$ & $0(0.08)$ \\
5 & $26(0.02)$ & $10(0.00)$ \\
6 & $6(0.05)$ & $11(0.08)$ \\
7 & $4(0.01)$ & $0(0.00)$ \\
8 & $28(0.00)$ & $0(0.01)$ \\
9 & $0(0.00)$ & $0(0.00)$ \\
10 & $0(0.08)$ & $0(0.00)$ \\
11 & $22(0.00)$ & $40(0.05)$ \\
12 & $0(0.00)$ & $0(0.00)$ \\
13 & $27(0.02)$ & $57(0.06)$ \\
14 & $22(0.00)$ & $40(0.00)$ \\
15 & $19(0.02)$ & $44(0.00)$ \\
16 & $16(0.03)$ & $26(0.00)$ \\
17 & $15(0.02)$ & $29(0.00)$ \\
18 & $22(0.00)$ & $6(0.00)$ \\
19 & $51(0.00)$ & $0(0.00)$ \\
20 & $29(0.05)$ & $51(0.00)$ \\
\hline
\end{tabular}

*Her değer iki tekrarın ortalamasıdır. Parantez içerisindeki değerler standart sapmaları göstermektedir

Biyofilm tabakasının ortadan kaldırılması için, 200 ppm konsantrasyonunda klor uygulaması ile, oluşan biyofilmlerin, altı suşta yaklaşık \%40-\%60 ( $\mathrm{P}<0.05)$ oranında, üç suşta ise yaklaşık \%20-\%30 $(\mathrm{P}<0.05)$ oranında azaldığı belirlenmiştir (Çizelge 1).

\section{Çelik Yüzeylerde Klor Uygulamaları}

Biyofilm oluşumunun, 200 ppm klor uygulaması ile bir suşta \%35 $(\mathrm{P}<0.05)$ oranında azaldığ 1 , iki suşta ise yaklaşık \%20-\%30 $(\mathrm{P}<0.05) \quad$ oranında azaldığı belirlenmiştir (Çizelge 2).

Biyofilmlerin, 200 ppm klor uygulaması ile 20 adet S. Aureus suşu arasından en fazla iki suşta yaklaşık $\% 45$ $(\mathrm{P}<0.05)$ oranında, dokuz suşta ise yaklaşık \%20-\%40 $(\mathrm{P}<0.05)$ oranında ortadan kaldırıldığ $1(\%)$ belirlenmiştir (Çizelge 2). 
Çizelge 2. S.aureus suşlarının biyofilm oluşumlarının klor uygulaması ile paslanmaz çelik yüzeylerde önlenmesi (A) ve ortadan kaldırılması (B) oranları $(\%)^{*}$

\begin{tabular}{ccc}
\hline Suş & A & B \\
\hline 1 & $0(0.02)$ & $45(0.02)$ \\
3 & $22(0.02)$ & $0(0.01)$ \\
4 & $35(0.02)$ & $29(0.00)$ \\
5 & $0(0.02)$ & $0(0.02)$ \\
6 & $0(0.00)$ & $20(0.03)$ \\
7 & $0(0.00)$ & $31(0.01)$ \\
8 & $12(0.06)$ & $17(0.02)$ \\
9 & $0(0.04)$ & $20(0.04)$ \\
10 & $6(0.01)$ & $40(0.00)$ \\
11 & $0(0.12)$ & $0(0.07)$ \\
12 & $0(0.05)$ & $9(0.02)$ \\
13 & $0(0.01)$ & $40(0.00)$ \\
14 & $0(0.00)$ & $23(0.05)$ \\
15 & $0(0.02)$ & $2(0.00)$ \\
16 & $0(0.03)$ & $40(0.00)$ \\
17 & $0(0.03)$ & $32(0.00)$ \\
18 & $0(0.03)$ & $0(0.04)$ \\
19 & $16(0.00)$ & $11(0.02)$ \\
20 & $29(0.02)$ & $46(0.00)$ \\
\hline
\end{tabular}

*Her değer iki tekrarın ortalamasıdır. Parantez içerisindeki değerler standart sapmaları göstermektedir

\section{Polistren Yüzeylerde Malik Asit Uygulamaları}

20 adet çiğ süt izolatı $S$. aureus suşunun malik asit $(\% 10$, w/v) uygulaması ile mikrotitrasyon plağında biyofilm oluşumunun engellenmesi ve oluşan biyofilmin ortadan kaldırılması oranları (\%) incelenmiştir. Biyofilm oluşumlarının $\% 10(\mathrm{w} / \mathrm{v})$ malik asit uygulaması ile bir suşta yaklaşık \%47 $(\mathrm{P}<0.05)$ ve altı suşta yaklaşık \%20-\%40 $(\mathrm{P}<0.05) \quad$ oranında engellendiği tespit edilmiştir (Çizelge 3). Oluşan biyofilmlerin ise, $\% 10(\mathrm{w} / \mathrm{v})$ malik asit uygulaması ile ise sekiz suşta yaklaşık \%70-\%85 $(\mathrm{P}<0.05)$ oranında, beş suşta yaklaşık \%50-\%65 $(\mathrm{P}<0.05)$ oranında ve yedi suşta ise $\% 30-\% 45 \quad(\mathrm{P}<0.05)$ oranında ortadan kaldırıldığı tespit edilmiştir (Çizelge 3).

Çizelge 3. S.aureus sușlarının biyofilm olușumlarının malik asit uygulaması (\%10) ile polistren yüzeylerde önlenmesi (A) ve ortadan kaldırılması (B) oranları (\%)

\begin{tabular}{ccc}
\hline Suş & A & B \\
\hline 1 & $4(0.00)$ & $43(0.00)$ \\
3 & $47(0.00)$ & $76(0.00)$ \\
4 & $20(0.07)$ & $85(0.00)$ \\
5 & $24(0.04)$ & $69(0.00)$ \\
6 & $24(0.00)$ & $77(0.00)$ \\
7 & $13(0.02)$ & $76(0.01)$ \\
8 & $38(0.00)$ & $38(0.02)$ \\
9 & $11(0.02)$ & $40(0.02)$ \\
10 & $1(0.00)$ & $37(0.00)$ \\
11 & $0(0.1)$ & $76(0.01)$ \\
12 & $0(0.06)$ & $60(0.02)$ \\
13 & $0(0.03)$ & $34(0.01)$ \\
14 & $0(0.00)$ & $85(0.03)$ \\
15 & $0(0.00)$ & $53(0.00)$ \\
16 & $0(0.04)$ & $36(0.07)$ \\
17 & $30(0.00)$ & $64(0.01)$ \\
18 & $20(0.00)$ & $62(0.01)$ \\
19 & $6(0.00)$ & $56(0.01)$ \\
20 & $8(0.00)$ & $45(0.00)$ \\
\hline
\end{tabular}

*Her değer iki tekrarın ortalamasıdır. Parantez içerisindeki değerler standart sapmaları göstermektedir
Çizelge 4. S.aureus sușlarının biyofilm oluşumlarının malik asit uygulaması $(\% 10)$ ile çelik yüzeylerde önlenmesi (A) ve ortadan kaldırılması (B) oranları (\%)*

\begin{tabular}{ccc}
\hline Suş & $\mathrm{A}$ & $\mathrm{B}$ \\
\hline 1 & $0(0.09)$ & $83(0.00)$ \\
2 & $0(0.19)$ & $83(0.00)$ \\
3 & $0(0.11)$ & $79(0.01)$ \\
4 & $0(0.2)$ & $79(0.00)$ \\
5 & $66(0.07)$ & $83(0.00)$ \\
6 & $30(0.3)$ & $73(0.01)$ \\
7 & $0(0.04)$ & $85(0.00)$ \\
8 & $0(0.08)$ & $82(0.00)$ \\
9 & $0(0.00)$ & $82(0.00)$ \\
10 & $8(0.05)$ & $81(0.00)$ \\
11 & $79(0.02)$ & $95(0.00)$ \\
12 & $15(0.06)$ & $95(0.00)$ \\
13 & $67(0.02)$ & $90(0.01)$ \\
14 & $20(0.02)$ & $60(0.00)$ \\
15 & $0(0.03)$ & $84(0.00)$ \\
16 & $0(0.07)$ & $90(0.00)$ \\
17 & $20(0.1)$ & $59(0.02)$ \\
18 & $14(0.07)$ & $73(0.00)$ \\
19 & $0(0.00)$ & $90(0.02)$ \\
20 & $21(0.15)$ & $90(0.00)$ \\
\hline *Her değer iki tekrarın ortalamasidır. Parantez içerisindeki değerler
\end{tabular}

standart sapmaları göstermektedir

\section{Celik Yüzeylerde Malik Asit Uygulamaları}

20 adet çiğ süt izolatı $S$. aureus suşunun malik asit $(\% 10, \mathrm{w} / \mathrm{v})$ uygulaması ile paslanmaz çelik kuponlarda biyofilm oluşmunun engellenmesi ve oluşan biyofilmin ortadan kaldırılması oranları (\%) incelenmiştir. Malik asit uygulaması $(\% 10, \mathrm{w} / \mathrm{v})$ ile ise biyofilm oluşumlarının üç suşta yaklaşık \%65-\%80 $\quad(\mathrm{P}<0.05)$ oranında ve dört suşta yaklaşık \%15-\%20 $(\mathrm{P}<0.05)$ oranında önlendiği tespit edilmiştir (Çizelge 4). Oluşan biyofilmlerin ise, altı suşta yaklaşık \%00-\%95 $(\mathrm{P}<0.05)$, on iki suşta yaklaşık \%70-\%85 $(\mathrm{P}<0.05)$, iki suşta ise yaklaşık \%60 $(\mathrm{P}<0.05)$ oranında ortadan kaldırıldığ1 tespit edilmiştir (Çizelge 4).

\section{TARTIŞMA}

Patojen bakterilerin oluşturdukları biyofilmler, endüstride önemli ekonomik kayıplara ve sağlık problemlerine yol açmaktadır. Sanayide sıklıkla kullanılan paslanmaz çelik, teflon ve polipropilen gibi yüzeyleri patojenik mikroorganizmalar kolaylıkla kontamine edebilmekte ve kolaylikla biyofilm oluşturabilmektedir. Günümüzde endüstride, yüzey sanitasyonu için kullanılan yaygın dezenfektanlar arasında perasetik asit, ozon ve klor yer almaktadır. Ancak mikroorganizmalar özellikle biyofilm oluşturduklarında zamanla kullanılan bu dezenfektanlara direnç kazanırlar (Mah ve T'oole, 2001).

Bu çalışmada, 200 ppm klor uygulaması ile biyofilm oluşumunun polistren yüzeylerde en fazla $\% 51$ oranında önlendiği, oluşan biyofilmin de en fazla \%57 oranında ortadan kaldırıldığı görülmüştür. Paslanmaz çelik yüzeylerde ise, 200 ppm klor uygulaması ile biyofilm oluşumunun en fazla \%35 oranında önlendiği, oluşan biyofilmin de en fazla \%46 oranında ortadan kaldırıldığ belirlenmiștir. 
Polistren yüzeylerde, kullanılan\%10 (w/v) malik asit uygulaması ile biyofilm oluşumunun en fazla $\% 47$ oranında önlendiği, oluşan biyofilmin de en fazla $\% 85$ oranında ortadan kaldırıldığı tespit edilmiştir. Paslanmaz çelik yüzeylerde, $\% 10(\mathrm{w} / \mathrm{v})$ malik asit uygulaması ile biyofilm oluşumunun en fazla \%79 oranında önlendiği, oluşan biyofilmin de en fazla $\% 95$ oranında ortadan kaldırıldığı belirlenmiștir.

Çalışmada, malik asit uygulaması, $S$. aureus biyofilmlerini klor uygulamasından daha etkin bir şekilde engellemiş ve ortadan kaldırmıștır. Kullanılan malik asit ve klorun, biyofilm oluşumunu ve oluşan biyofilmi uzaklaştırmadaki etkinliklerindeki fark antimikrobiyal aktivitelerinin farklı olmasından ileri gelmektedir. Klor, hücrelerin zarında bulunan lipid-protein yapıya etki ederek toksik klorlu bileşikleri oluşturur ve hücreden makromoleküllerin kaybına neden olur (Haas ve Engelbrecht, 1980). Organik asitler ise birçok bakteri üzerinde antimikrobiyal etkiye sahip bulunmuștur (Eswarandam ve ark., 2004; Akbas ve Ölmez, 2007). Organik asitlerin hücre membranından geçerek hücre sitoplazmasını asidifiye ettiği, hücreninde sitoplazmanın iç $\mathrm{pH}$ değerini dengelemek için protonları hücre dışına pompaladığı ve bu sırada enerji kaybettiği belirtilmiștir. Ayrıca organik asitlerin hücre zarına zarar verdiği ve DNA'yı denatüre ettiği bildirilmiştir (Lou ve Yousef, 1999; Ricke 2003).

S. aureus biyofilmlerinin hem klor hem de malik asit uygulamaları ile ortadan kaldırılma oranları, biyofilmlerin önlenme oranlarından daha fazla bulunmuştur. Ayrıca, çelik yüzeylerde biyofilm oluşumunun yüksek oranlarda (>\%80) uzaklaştırılabildiği suş sayısı ve azalma oranları polistren yüzeylere göre çok daha yüksek bulunmuştur. Mikroorganizmaların biyofilm oluşturmalarında biyofilm oluşturacakları yüzeyin yapısı, hidrofilik veya hidrofobik karakterde oluşu önemlidir.Yüzeye yapışarak biyofilm oluşturabilme, aynı zamanda bir bakterinin sahip olduğu yüzey yapılarının karakteristiği ile de ilgili olabilir (Corpe, 1980; Williams ve Fletcher, 1996).Önceki çalışmalarda mikroorganizmaların hidrofobik özellikteki polistren yüzeylere paslanmaz çelik gibi hidrofilik yüzeylerden daha hızlı yapışabildikleri rapor edilmiştir (Corpe, 1980; Williams ve Fletcher, 1996; Marques ve ark., 2007). Bu çalışmada da, S. Aureus suşları polistren yüzeylere daha hızlı yapışmış ve daha dayanıklı biyofilmler oluşturmuş olabilir. Bu nedenle çelik yüzey gibi hidrofilik karakterdeki yüzey materyallerinin gıda ile temas eden yüzeylerde kullanımı doğru bir yaklaşım olacaktır.

\section{SONUÇ}

$\mathrm{Bu}$ güne kadar yapılan çalışmalarda, $S$. aureus suşlarınn biyofilmleri üzerinde malik asitin antibiyofilm özelliği incelenmemiş̧ir. Özellikle gıda sanayinde biyofilmlerin oluşumunun önlenmesi ve oluşan biyofilmin azaltılması daha sonraki kontaminasyonlar ile alet ve ekipmanın korozyonunun önlenmesi açısından önemlidir. $\mathrm{Bu}$ çalışmada uygulanan doğal antibiyofilm ajanı olarak malik asitin daha farklı konsantrasyon ve sürelerle de uygulanabilirliğinin ve bu uygulamaların büyük ölçekte optimize edilerek sanayide kullanılabilirliğinin araştırılması gerekmektedir.

Bu nedenle, çalışmadan elde edilen sonuçlar, malik asit uygulamasının, S. aureus biyofilmlerinin kontrolünde, gıda sanayinde uygulanan klor gibi çevre ve canlılar için toksik etkileri olan kimyasallara alternatif olabileceğini göstermektedir.

\section{TEŞEKKÜR}

$\mathrm{Bu}$ çalışma Gebze Teknik Üniversitesi tarafindan desteklenmiştir.

\section{KAYNAKLAR}

Akbas, M.Y., Kokumer T., 2015. The prevention and removal of biofilm formation of Staphylococcus aureus strains isolated from raw milk samples by citric acid treatments. International Journal of Food Science and Technology, 50(7): 1666-1672.

Akbas, M.Y., Olmez, H. 2007. Inactivation of Escherichia coli and Listeria monocytogenes on iceberg lettuce by dip wash treatments with organic acids. Letters in Applied Microbiology, 44: 619-624.

Arciola, C. R., Campoccia, D., Ravaioli, S., Montanaro, L. 2015. Polysaccharide intercellular adhesin in biofilm: structural and regulatory aspects. Frontiers in Cellular and Infection Microbiology, 5:7. doi: 10.3389/fcimb.2015.00007.

Corcoran, M.., Morris, D., De Lappe, N., O'Connorb, J., Lalor, P., Dockery, P., Cormican M. 2014. Commonly used disinfectants fail to eradicate Salmonella enterica biofilms from food contact surface materials. Applied and Environmental Microbiology, 80 (4): 1507-1514.

Corpe, WA. 1980. Microbial surface components involved in adsorption of microorganisms onto surfaces. In: Bitton G, Marshall KC, editors. Adsorption of microorganisms to surfaces. New York: John Wiley and Sons; p. 105-144.

Cos, P., Tote, K., Horemans, T., Maes. L. 2010. Biofilms an extra hurdle for effective antimicrobial therapy. Current Pharmaceutical Design, 16: 2279-2295.

Di Ciccio, P., Vergara, A., Festino, A.R., Paludi, D., Zanardi, E., Ghidini, S., Ianieri, A. 2015. Biofilm formation by Staphylococcus aureus on food contact surfaces: Relationship with temperature and cell surface hydrophobicity.Food Control, 50: 930-936.

Donlan, R.M., Costerton, J.W. 2002. Biofilms: survival mechanisms of clinically relevant microorganisms. Clinical Microbiology Reviews, 15: 167-193.

Durlu-Özkaya, F., Cömert, M. 2008. Gida zehirlenmelerinde faktörler. Türk Hijyen ve Deneysel Biyoloji Dergisi, 65(3):149-158.

Eswaranandam, S., Hettiarachchy, N.S., Johnson, M.G. 2004. Antimicrobial activity of citric, lactic, malic, or tartaric acids and nisin-incorporated soy protein film against Listeria monocytogenes, Escherichia coli, O157:H7, and Salmonella Gaminara. Journal of Food Science, 69: 79-84.

Flemming, H.C., Wingender, J. 2010. The biofilm matrix. Nature Reviews Microbiology, 8(9):623-633. 
González-Fandos, E., Herrera, B. 2013. Efficacy of malic acid against Listeria monocytogenes attached to poultry skin during refrigerated storage.Poultry Science,92(7):1936-1941.

Günaydin, B., Aslantaş, Ö., Demir, C. 2011. Detection of superantigenic toxin genes in Staphylococcus aureus strains from subclinical bovine mastitis. Tropical Animal Health and Production, 43(8): 1633-1637.

Haas C.N., Engelbrecht. R.S. 1980. Physiological alterations of vegetative microorganisms resulting from chlorination. Journal of Water Pollution Control Federation, 52:1976-1989.

Karagözlü, C., Karagözlü, N. 2004. Süt endüstrisinde deterjan ve dezenfektan kalıntılarının önemi. Harran Universitesi Ziraat Fakültesi Dergisi, 8(3/4): 73-81

Knowless, J.R., Roller, S., Murray, D.B., Naidu, A.S. 2005. Antimicrobial action of carvacrol at different stages of dual species biofilm development by Staphylococcus aureus and Salmonella enterica Typhimurium. Applied and Environmental Microbiology, 71: 797-803.

Lou, Y. Yousef, A.E. 1999. Characteristics of Listeria monocytogenes important to food processors. In Listeria, Listeriosis and Food Safety, 2nd Ed. (E.T. Ryser and E.H. Marth, eds.), 131-224, Marcel Dekker, Inc., New York, NY.

Lu, Huiying J., Breidt, Jr., Frederick, Pérez-Díaz, Ilenys M., Osborne, Jason A. 2011. Antimicrobial effects of weak acids on the survival of Escherichia coli O157:H7 under anaerobic conditions. Journal of Food Protection, 74(6):893-898.

Mah, T.F.C., O’Toole, G.A. 2001. Mechanisms of biofilm reisitance to antimicrobial agents. Trends in Microbiology, 9: 34-39.

Marques, S.C., Rezende, J.G.O.S., Alves, L.A.F., Silva, B.C, Alves, E., Abreu, L.R., Piccoli, R.H. 2007. Formation of biofilms by Staphylococcus aureus on stainless steel and glass surfaces and its resistance to some selected chemical sanitizers. Brazilian Journal of Microbiology, 38: 538-543.

Mertz, D., Frei, R., Jaussi, B., Tietz, A., Stebler, C., Flückiger, U., Widmer, A.F. 2007. Throat swabs are necessary to reliably detect carriers of Staphylococcus aureus.Clinical Infectious Disease, 45(4):475-457.

Peles, F., Wagner, M., Varga, L., Hein, I., Rieck, P., Gutser, K., Keresztúri, P., Kardos, G., Turcsányi, I., Béri, B., Szabó, A. 2007. Characterization of Staphylococcus aureus strains isolated from bovine milk in Hungary. International Journal of Food Microbiology,118 (2): 186-193.

Rashid, Z., Farzana, K., Sattar, A., Murtaza, G. 2012. Prevalence of nasal Staphylococcus aureus and methicillin-resistant Staphylococcus aureus in hospital personnel and associated risk factors. Acta Poloniae Pharmaceutica, 69 (5): 985-991.
Raybaudi-Massilia, M.R., Melgar, J.M, Sobrıno

López, A. Martın-Belloso, A. 2009. Inactivation of Listeria monocytogenes, Salmonella interitidis and Escherichia coli $\mathrm{O} 157: \mathrm{H} 7$ and shelf life extension of fresh-cut pears using malic acid and quality stabilizing compounds. Journal of Food Quality, 32,(5): 539-565.

Ricke, S.C. 2003. Perspectives on the use of organic acids and short chain fatty acids as antimicrobials. Poultry Science, 82: 632-639.

Scherrer, D., Corti, S., Muehlherr, J. E., Zweifel, C., Stephan, R. 2004. Phenotypic and genotypic characteristics of Staphylococcus aureus isolates from raw bulk-tank milk samples of goats and sheep. Veterinary Microbiology, 101: 101-107.

Simoes, M. 2011. Antimicrobial strategies effective against infectious bacterial biofilms. Current Medicinal Chemistry, 18: 2129-2145.

Singla, R., Goel, H., Ganguli, A. 2014. Novel synergistic approach to exploit the bactericidal efficacy of commercial disinfectants on the biofilms of Salmonella enterica serovar Typhimurium. Journal of Bioscience Bioengineering,118(1):34-40.

Srey, S., Jahid, I.K., Ha, S.D. 2013. Biofilm formation in food industries: a food safety concern. Food Control, 31(2):572-585.

Stepanovic, S., Vukovic, D., Dakic, I., Savic, B., SvabicVlahovic, M. 2000. A modified microtiter-plate test for quantification of staphylococcal biofilm formation. Journal of Microbiological Methods, 40: 175-179.

Syne, S., Ramsubhag, A. Adesiyun, A. 2013. Microbiological hazard analysis of ready-to-eat meats processed at a food plant in Trinidad, West Indies. Infection Ecology and Epidemiology, 3. doi:http://dx.doi.org/10.3402/iee.v3i0.20450

Van Belkum, A., Verkaik, N.J., de Vogel, C.P., Boelens, H.A., Verveer, J., Nouwen, J.L., Verbrugh, H.A., Wertheim, H.F. 2009. Reclassification of Staphylococcus aureus nasal carriage types. Journal of Infectious Disease, 199(12):1820-1826.

Williams, V., Fletcher, M. 1996. Pseudomonas fluorescens adhesion and transport through porous media are affected by lipopolysaccharide composition. Applied and Environmental Microbiology, 62: 1004.

Xu,C., Yagiz, Y., Hsu, W.Y., Simonne, A., Lu, J., Marshall, M.R. 2014. Antioxidant, antibacterial, and antibiofilm properties of polyphenols from muscadine grape (Vitis rotundifolia Michx.) pomace against selected foodborne pathogens, Journal of Agricultural Food Chemistry, 62(28): 6640-6649.

Zinke, C., Winter, M. , Mohr, E., Krömker, V. 2012. Occurrence of methicillin-resistant Staphylococcus aureus in cheese produced in German farm-dairies. Advances in Microbiology, 2: 629-633. 